\title{
Lope, leitor de Jorge Ferreira de Vasconcelos
}

\section{Lope, Reader of Jorge Ferreira de Vasconcelos}

\author{
Silvina Pereira \\ Centro de Estudos Clássicos \\ Universidade de Lisboa \\ PORTUGAL \\ silvinapereira@netcabo.pt
}

[Hipogrifo, (issn: 2328-1308), 3.2, 2015, pp. 179-201]

Recibido: 16-01-2015 / Aceptado: 17-03-2015

DOI: http://dx.doi.org/10.13035/H.2015.03.02.12

Resumo. Este trabalho toma como ponto de partida uma afirmação de Eugenio Asensio, segundo a qual o maior admirador de Jorge Ferreira de Vasconcelos e das suas comédias teria sido Lope de Vega, facto que se comprova analisando as afinidades apontadas por aquele estudioso entre a Eufrosina (1555) e a Dorotea (1632) e, em certa medida até, com a Aulegrafia (1619). Outros pontos de contacto entre a vida e a obra destes dois grandes vultos do teatro ibérico, serão aqui focados no sentido de se perceber de que maneira se processou a recepção das obras do comediógrafo quinhentista português por Lope de Vega.

Palavras chave. Jorge Ferreira de Vasconcelos, Lope de Vega, Teatro, Eufrosina, Aulegrafia, Dorotea.

Abstract. This work takes as its starting point Eugenio Asensio's affirmation that the greatest admirer of Jorge Ferreira de Vasconcelos and his comedies would have been Lope de Vega. He attempts to prove this thesis by pointing out the similarities between the Eufrosina (1555) and Lope's La Dorotea (1632) and, to a certain extent, even the Aulegrafia (1619). Other points of contact between the lives and works of these two great figures of the Iberian theater are also considered, in order to understand how Lope de Vega processed his reception of the works of the Portuguese comedy writer of the sixteenth century.

Keywords. Jorge Ferreira de Vasconcelos, Lope de Vega, Theater, Eufrosina, Aulegrafia, Dorotea. 
«Pero su más glorioso admirador fue Lope de Vega, cuya Dorotea tiene no pocas afinidades con la Eufrosina».

Eugenio Asensio

\section{PRÓLOGO}

O comediógrafo Jorge Ferreira de Vasconcelos tem sido uma figura pouco estudada pela crítica literária portuguesa, quer no que respeita à obra, quer no que concerne à sua vida. Graças a uma investigação que temos vindo a realizar nos últimos anos foi possível conhecer, a partir de documentação descoberta em arquivos, o itinerário da vida do escritor sobretudo quanto à sua carreira profissional, bem como confirmar algumas informações biográficas?.

Paralelamente a esse trabalho de pesquisa, algumas das suas comédias têm sido apresentadas no palco, realizando-se um labor dramatúrgico que visa resgatar para a cena a sua obra dramática². Dos textos que lhe são atribuídos, somente as três comédias, Eufrosina, Ulysippo, Aulegrafia e o Memorial das Proezas da Segunda Távola Redonda, são hoje conhecidos, encontrando-se a restante produção desaparecida.

Jorge Ferreira de Vasconcelos estreia-se no prelo, em 1554, com o livro de cavalaria Sagramor, que está descrito e catalogado mas que se encontra desaparecido. Em 1555 sai a editio princeps da Comedia Eufrosina, que teve fortuna editorial assinalável e reconhecimento ao tempo, dado que contou com várias publicações (1560, 1561 e 1566). Ao contrário da Comedia Ulysippo que logo após a sua impressão entrou no Índice de 1561 e nunca mais de lá saiu, a Eufrosina circulou livremente até ter entrado no Índice de 1581. Felizmente esta proibição não transpôs

1. Jorge Ferreira de Vasconcelos, cortesão e escritor do Renascimento português. Nasceu na segunda ou terceira década do século XVI. Seu pai, António Dias Pereira, era natural de Coimbra. Através de documentação comprovativa sabe-se que exerceu os seguintes ofícios e cargos: moço de câmara do Infante D. Duarte, moço de câmara de D. João III, escrivão do tesouro da casa real, Tesoureiro do Tesouro Real e Tesoureiro do Armazém da Guiné e Índia. Foi casado com D. Ana de Souto, senhora nobre. Teve dois filhos. Perdeu um filho jovem, Paulo Ferreira em 1578, na batalha de Alcácer Quibir. Confirma-se ainda que sua filha, Briolanja Mendes de Vasconcelos, casou com D. António de Noronha, futuro editor das edições seiscentistas das comédias Ulysippo e Aulegrafia. Morreu em 1584-1585 e foi enterrado no cruzeiro central da Igreja da Trindade, desaparecida no Terramoto de Lisboa (Pereira, 2010, pp. 61 e 62). 2. A Comedia Eufrosina teve estreia mundial a 27 de Março de 1995, na Igreja do Convento dos Inglesinhos, com o patrocínio da Comissão Nacional para as Comemorações do Descobrimentos Portugueses com direcção de Silvina Pereira e produção do Teatro Maizum. Em 2011, envolvendo os alunos de duas escolas artísticas, a Escola de Dança do Conservatório Nacional e a Escola de Música do Conservatório Nacional, foi apresentada uma versão juvenil da Comedia Eufrosina, em Abril de 2011, no Estúdio 7 da EDCN, com direcção de Silvina Pereira. A Comedia Ulysippo, teve estreia mundial a 18 de Dezembro de 1997, no Teatro da Trindade, integrada nas Comemorações dos 850 anos da Tomada de Lisboa, uma iniciativa da Câmara Municipal de Lisboa, em co-produção com o Teatro Nacional D. Maria II. Direcção de Silvina Pereira e produção do Teatro Maizum. 
fronteiras, pelo que, em tempo de Monarquia Dual, a Eufrosina era lida e admirada em território castelhano.

No propósito de melhor enquadrar a problemática da recepção da obra de Jorge Ferreira de Vasconcelos por Lope de Vega, recordemos as datas de edição dos seus textos e o momento em que deram entrada em Índices inquisitoriais portugueses:

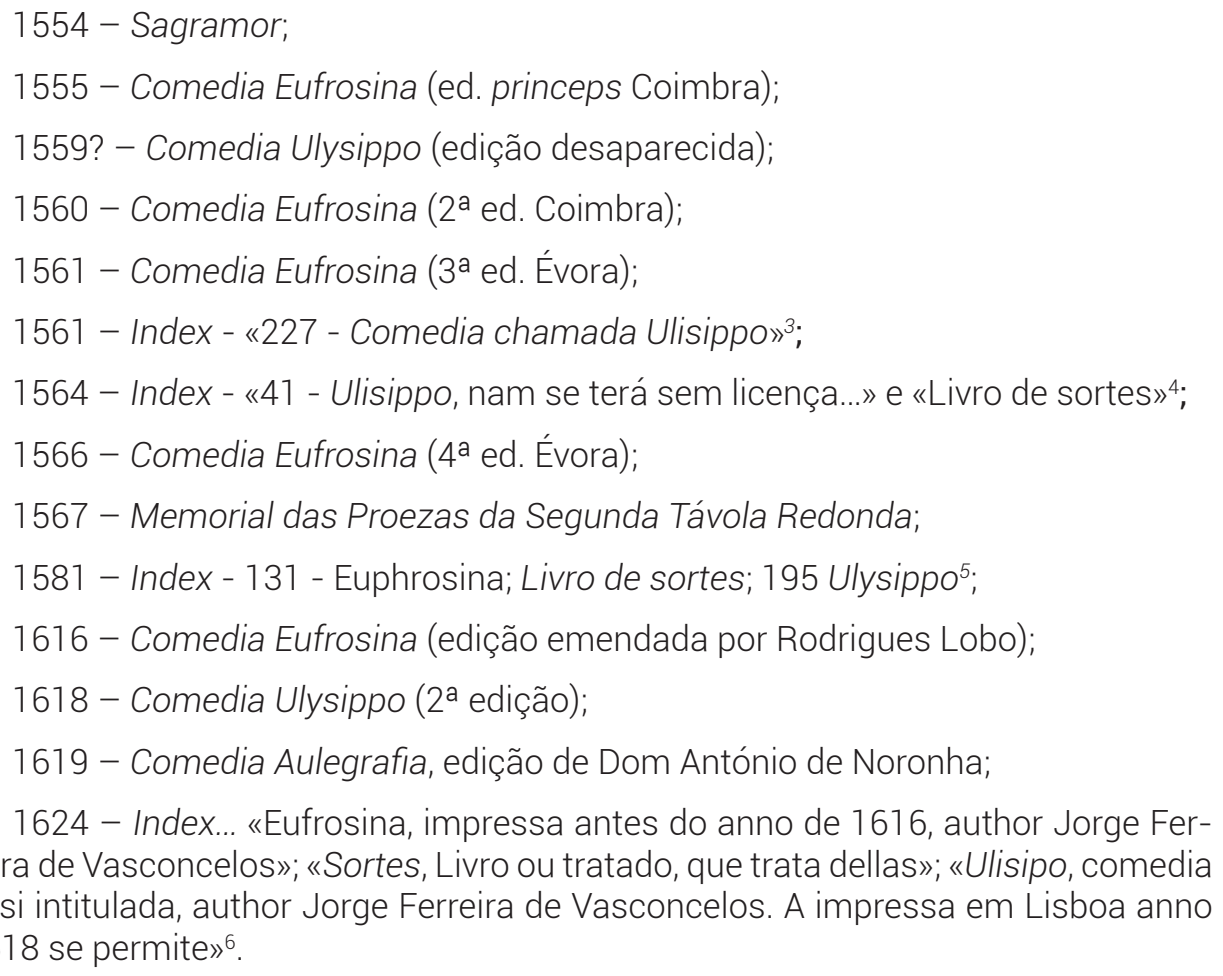

\section{TEMPO E CIRCUNSTÂNCIAS: 1583, LOPE DE VEGA EM LISBOA}

Quando Lope de Vega, trocando os estudos pelas armas, desembarcou em Lisboa em Junho do ano de 1583, a bordo do galeão S. João, tinha 21 anos, e começava a percorrer um longo caminho de vida que duraria até aos 74 anos. Integrava a expedição que iria partir à conquista dos Açores a qual, sob o comando do Marquês de Santa Cruz, daria o golpe de morte às pretensões ao trono de D. António Prior do Crato.

Nesse ano, em Lisboa, Jorge Ferreira de Vasconcelos estava prestes a sair do grande palco da vida, o que viria a acontecer por volta de 1585. Cortesão e come- 
diógrafo, tesoureiro do Rei e autor de uma obra apreciável, Ferreira de Vasconcelos, ao contrário de Lope, não tinha por hábito assinar as suas obras. O facto de terem saído impressas sem nome de autor, contribuiu para que o dramaturgo português ficasse para a posteridade sem rosto e quase sem biografia.

Em 1583, era tempo de Monarquia Dual. Num clima de abatimento, de perda e de catástrofe não deveria ser nada fácil assistir à derrocada nacional que teve início com a morte do príncipe herdeiro, D. Sebastião, em 4 de Agosto de 1578 e, com ele, ao desaparecimento da flôr da juventude do reino, entre ela, a do mancebo Paulo Ferreira, filho do nosso comediógrafo, conforme nos é dito por João Franco Barreto e Barbosa Machado. Camões, que terá morrido antes do mês de Março de 1580, não sobreviveu muito mais a esta imensa tragédia nacional?

Jorge Ferreira de Vasconcelos mostra nos textos das suas comédias um assinalável sentimento anti-castelhano ${ }^{8}$. No entanto, o comediógrafo não fez parte da lista dos simpatizantes e seguidores de Dom António Prior do Crato, embora a sua grande admiração pelo Infante Dom Luís, pai de Dom António, assim o pudesse fazer supor ${ }^{9}$.

7. Em Retratos de Camões, Vasco Graça Moura considera que a miniatura da Casa de Rio Maior, o primeiro retrato «robot» pintado a partir de depoimentos de marujos que tinham convivido com o poeta 14 anos antes em Goa, e onde o épico aparece com uma coroa de louros, é uma peça importante para a conjectura da data de morte de Camões. Trata-se de uma encomenda feita por um nobre residente em Goa, Fernão Teles de Menezes, a um artista local, para ser oferecida ao vice-rei D. Luís de Ataíde. Segundo Graça Moura, Camões terá morrido, não a 10 de Junho de 1580, mas antes de 4 de Março de 1580, data de saída da armada desse ano de Lisboa, de modo que a notícia chegasse a Goa em Setembro desse ano, tendo levado Fernão Teles de Menezes a encomendar logo esse retrato de homenagem póstuma, para obsequiar o vice-rei, irmão de um dos grandes amigos de Camões, retrato que deveria ter ficado pronto antes de 9 de Março de 1581, data em que D. Luís de Ataíde morreu (Moura, 2014, pp. 49-50).

8. Em «Ventos de Espanha. La Eufrosina de Jorge Ferreira de Vasconcelos. Uma tradução espanhola pouco conhecida», um estudo de 2008, tive oportunidade de comparar algumas cenas das edições quinhentistas com a de Rodrigues Lobo de 1616 e a tradução de 1631, por forma a encontrar a tendência da tradução castelhana de Fernando de Ballesteros y Saavedra. Na cena $7^{a}$ do I Acto, Cariófilo diz: "Ora vinde ca, por duas cousas dou contino graças a Deos. A primeira por me fazer português e não castelhano, nem algum desoutros cabrões, mais barbaros do juizo do que eles julgam a nossa lingoa» (Vasconcelos, Eufrosina, p. 13). Como foi referido nesse estudo a tradução optou pela omissão «castelhano» e «cabrões», presente na versão original, seguindo a versão expurgada de Rodrigues Lobo, um exemplo de supressão da referência anti-castelhana. Veja-se ainda como na Aulegrafia a personagem Agrimonte de Guzmán, sevilhano, deliciosa caricatura do castelhano vaidoso, fanfarrão e letrado é gozado pelas personagens portugueses pela sua facúndia. Na mesma comédia e numa cena hilariante o criado castelhano Xarales, vai queixando-se do seu senhor pelo seu sentido pouco prático em matérias amorosas. $\mathrm{Na}$ Ulysippo aparece também uma personagem denominada de Sevilhana, mas num contexto diferente. 9. Conforme se lê na Comedia Aulegrafia na menção feita por Agrimonte, personagem castelhana em visita a Lisboa: «Queria assentar com el Ifante Don Luys, cuya fama de magnanimo Principe, favorecedor de toda abilidad, buela por el mundo». Mais tarde, Germínio não deixará de comentar a esperteza do castelhano:«Estes como são de se apegar ao melhor: em pondo olhos em Portugal, logo amarrão suas esperanças no Ifante, que é a gema delle» (Vasconcelos, Aulegrafia, fol. 72). 
Em tempo de Filipe II, Jorge Ferreira de Vasconcelos, que fora Tesoureiro do Tesouro Real de D. Sebastião, será conduzido a 4 de Outubro de 1580 até finais de Dezembro de 1583 no cargo de Tesoureiro do Armazém da Guiné e da Índia ${ }^{10}$.

\section{3 - Lisboa «Cais do mundo»}

Ano de 1583, mês de junho, Lisboa. Dois homens geniais respiram o ar da mesma cidade. Lisboa, «cais do mundo», debruçada sobre o luminoso Tejo, retumba de actividade febril. 0 rio está salpicado de galeras, galeões, naus grossas e barcos de menor grandeza fretados a diferentes nações. Milhares de soldados veteranos espanhóis, alemães, companhias de italianos e uma de portugueses preparam-se para aquele que será o último esforço de guerra, uma operação militar que porá termo à resistência da ilha Terceira, transformando a ilha num «teatro de horrores», uma tragédia que marcará o início do domínio filipino.

Seja-nos permitido um pouco de ficção, embora verosímil. Podemos imaginar o jovem Lope a cruzar-se com o sexagenário Vasconcelos, que se dirigia, como sempre, para um dia de trabalho no paço, como Tesoureiro do Armazém da Guiné e da Îndia.

Vasconcelos desce a calçada da jornada da sua existência. É um homem cansado, desgostoso, reflectindo sobre o absurdo e a fugacidade da vida ${ }^{11}$. Lope de Vega, o poeta soldado, sobe essa calçada em passo ágil e nervoso, pois tem pela frente um futuro glorioso, inclusive o enamoramento pela bela Elena Osório, nesse mesmo ano, quando regressar a Madrid.

Voltemos para o mundo dos estudos literários, nomeadamente para a recepção das obras de Vasconcelos em Espanha.

\section{RECEPÇÃO EM ESPANHA}

A recepção da obra de Vasconcelos em Espanha pode documentar-se a partir de elementos colhidos nas obras seguintes:

1552 - Egloga Baltea (Veneza, 1552), de Alonso Núñez de Reinoso;

1605 - Fastigimia de Tomé Pinheiro da Veiga;

1605 - Libro de entretenimiento de la pícara Justina de Francisco Lopez de Úbeda;

1621 - La Filomena de Lope de Vega;

1623 - Inventário da Biblioteca do Conde Gondomar, onde aparece mencionado o Manuscrito II - 1519 da Comedia Aulegrafia;

10. Veja-se a carta de quitação de D. Filipe I, onde se lê que «Jorge Ferreira de Vascocomçelos» no período de «quatro d'Outubro de quinhemtos e oitemta - ate fim de Dezembro de oitemta e três», «serujo de thesoureiro do Allmazem de Guyne e Jmdya» (Pereira, 2010, p. 704).

11. Veja-se os versos «encontrados entre os seus papéis», inseridos no final da edição da Comedia Aulegrafia de 1619. 
1631 - La Eufrosina. Tradução castelhana de Fernando Ballesteros de Saavedra, com prefácio de Francisco de Quevedo;

1632 - La Dorotea de Lope de Vega.

Eugenio Asensio refere que sobre a Eufrosina há uns versos de Alonso Núñez de Reinoso (1492?-1552) «incluídos no Ensayo de Gallardo, III, 994, que podrían induzir a la sospecha de que era una dama conocida» ${ }^{2}$. Lembra o lusitanista que na Egloga Baltea, incluída nas suas obras (Veneza, 1552), relata uma viagem a Portugal, e, depois de mencionar os pastores de Bernardim Ribeiro, diz:

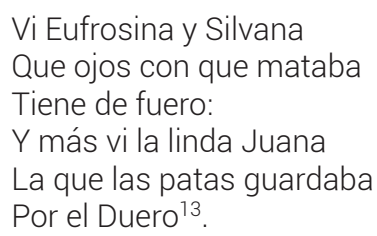

Por seu turno, Jean Subirats em Jorge Ferreira de Vasconcelos - Visages de son oeuvre et de son temps, no tomo I, assinala que não é na sociedade do tempo que se deve procurar uma jovem com o nome de Eufrosina, que possa ter servido de modelo para o nome da comédia de Ferreira de Vasconcelos. Para ele, o comediógrafo tomou este nome da Officina de Ravisius Textor, indicando inclusive a edição consultada, a de 1532, onde na folha da esquerda, o fólio $123 \mathrm{v}$ se lê Zelotypi e, no fólio da direita, o 124, no prolongamento da linha da folha anterior aparece uma lista das Castissimi, e nela se encontrando o nome de Euphrosina. Foi aqui, segundo Subirats, nesta bela edição que, seguramente, Vasconcelos encontrou o nome das duas personagens principais ${ }^{14}$.

No entanto, poderá haver verdade nas duas informações, aparentemente incompatíveis, ou seja, a premissa de Subirats pode estar certa tal como a que nos propõe a intuição de Asensio.

Eugenio Asensio, em Alonso Núñez de Reinoso, «Gitano Peregrino» y su Égloga Baltea, diz-nos que Reinoso se apaixonou de tal forma pela poesia de Bernardim que, nas suas trovas melancólicas, as mais das vezes parece uma «personagem ribeiresca» ${ }^{15}$. Era seu hábito não nomear o nome dos amigos, o que não impede a identificação destes, já que na sua obra se projecta a fonte de inspiração, como acontece com a Écogla II de Jano e de Franco, de Bernardim. Jano, o pastor portu-

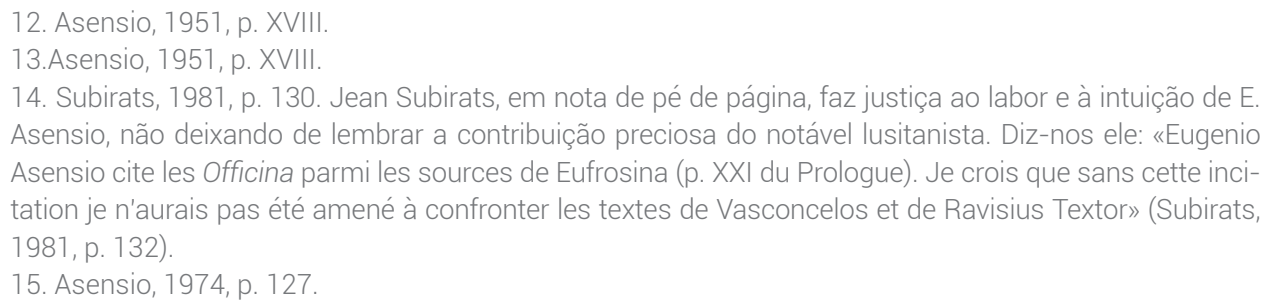


guês, vê lavar-se e olhar-se no Tejo Joana, a guardadora de patos, e ferido de amor persegue-a ${ }^{16}$.

Para Asensio, as pegadas de Bernardim são muito evidentes na obra deste poeta inquieto e auto-caracterizado como "gitano peregrino», que nasceu em Guadalajara mas que cedo passou os seus anos de maturidade em Portugal, terra de exílio temporário ${ }^{17}$.

Constance Hubbard Rose, em The Lament of Sixteenth-Century Exile, refere a sua estadia em Portugal e o seu convívio com escritores portugueses como Sá de Miranda e Bernardim Ribeiro, contacto que passou pelo círculo de Basto, o círculo literário a que Sá de Miranda pertencia, e que terá vivido e estudado em Coimbra na década de quarenta. Diz-nos ela que: «He mentions both Portuguese localities in his poems. Perhaps, like Diego Núñes de Reinoso, he was connected with the university, although he is mute about his activities, in any, in Coimbra» ${ }^{18}$.

Segundo Asensio, a escrita da Comedia Eufrosina terá acontecido em Coimbra, pelos anos 1542/1543, e a peça teria sido muito provavelmente aí representada, segundo se infere pela leitura do texto. Por isso, faz todo o sentido que a ela se refira Reinoso e que Asensio estabeleça esta ligação. Também é de lembrar que na Comedia Aulegrafia de 1619 a um dado passo lêem-se os nomes Sá de Miranda e do escudeiro Chiado, o que não faz sentido mas, na versão manuscrita do texto, os nomes que aparecem mencionados por Vasconcelos são os de Sá de Miranda e Bernardim Ribeiro.

Outros ecos escritos de recepção à Comedia Eufrosina encontram-se nas obras dos escritores Pinheiro da Veiga e López de Úbeda, em 1605.

Tomé Pinheiro da Veiga (1571-1656), um escritor português a viver em Valladolid, então capital de Castela e Leão, publica no ano de 1605 uma obra curiosa, a Fastigimia, mais apropriadamente chamada Fastigínia, isto é, «fastos geniais». Encontram-se aqui duas breves referências à Comedia Eufrosina: a primeira, onde se lê:

Porque, ordinariamente, têm um modo de falar metafórico e de translações, e não vulgar, nem ordinário, em lugar dos anexins e rifões dos nossos sengos e velhos, ao modo da nossa Eufrosina, com que fazem alegre e aprazível a conversação ${ }^{19}$;

e a segunda, uma menção à gentil personagem Sílvia de Sousa, medianeira dos amores do primo Zelótipo com Eufrosina, aqui mencionada num contexto pouco claro:

17. Acompanhou a famosa judia Gracia Nasi em Portugal e depois em Itália. Segundo a tradição, terá sido ele a levar o Livro de Bernardim Ribeiro para Ferrara, onde viria a sair impresso em 1554.

18. Rose, 1971, p. 36.

19. Veiga, 2011, p. 247. 
Tornando-me à igreja, desta e de outras vezes que nos ficou conhecimento, com que me pediram algumas curiosidades que trouxe, e com elas Ihes mandei um soneto, para a senhora Sílvia de Sousa em particular ${ }^{20}$.

Também no Libro de entretenimiento de la pícara Justina, de 1605, novela composta pelo licenciado Francisco López de Úbeda, natural de Toledo, se alude à primeira comédia de Ferreira de Vasconcelos, sendo igualmente referida por duas vezes a Eufrosina. No Prologo Sumario, ao início da obra, lê-se o seguinte: «Y así, no ay enredo en Celestina, chistes en Momo, simplezas en Lázaro, elegancias en Guevara, chistes en Eufrosina, enredos en Patrañuelo, cuentos en Asno de oro» ${ }^{21}$; e no Capitulo segundo «dígolo por un librito intitulado la Eufrosina, que ley siendo donzella» ${ }^{22}$.

À vista do atrás exposto, pode concluir-se que as edições quinhentistas da Eufrosina eram conhecidas, apreciadas, e circulavam com relativa liberdade em terras castelhanas. Menéndez y Pelayo assinalava que: «Mucho antes de salir a la luz la edición expurgada de 1616 era conocida y celebrada entre nosotros la obra de Jorge Ferreira, que en Castilla no estuvo prohibida nunca» ${ }^{23}$.

Em 1621, Lope de Vega Carpio (1562-1635), segundo o parecer de Asensio, «su más glorioso admirador» ${ }^{24}$ dá ecos da Eufrosina em La Filomena con otras diversas Rimas, Prosas, y Versos. Na nona epístola escrita em verso a D. Juan de Arguijo, lembra:

Dizen que un Português cada mañana

(Oyd si era discreto y Cortesano,

Si bien no afecto a gente Castellana)

Dezia (y con razon que no era en vano)

Gracias as dou Siñor por as mercedes

De naon facerme bestia, o Castellano ${ }^{25}$.

Também Lope de Vega parece citar de forma livre uma das primeiras frases da Eufrosina ( $1^{\text {a }}$ cena - I acto), não a partir da edição expurgada de Lobo, saída em 1616, em que falta a frase «e nam castelhano», mas de uma edição original quinhentista ${ }^{26}$.

21. López de Úbeda, Libro de Entretenimiento de La Pícara Justina, fol. 6.

22. López de Úbeda, Libro de Entretenimiento de La Pícara Justina, fol. 71. Na edição da Pícara Justina de 1854, o título da comédia de Vasconcelos vem mal indicado, aí se lê «Dígolo por un librito intitulado la EUROSINA» (López de Úbeda, 1854, p. 69).

23. Menéndez y Pelayo, 1910, p. CCXXXVII.

24. Asensio, 1951, p. LXXXVIII.

25. Lope de Vega, La Filomela, p. 188

26. Segundo Eugenio Asensio, a tradução foi feita a partir da edição revista pelo autor, a de 1560, enquanto para Aubrey Bell teria sido a partir da edição de 1561 (Bell, 1919, p. XV). A edição castelhana coincide com a edição censurada de Rodrigues Lobo quando omite as referências anti-castelhanas. 


\section{A TRADUÇÃo CASTELHANA DE FERNANDO DE BALLESTEROS DE 1631}

Antes de prosseguirmos com os indícios da recepção lopiana, que continuarão visíveis na Dorotea, de 1632, lembremos que no ano de 1631 foi publicada a $1^{\text {a }}$ edição castelhana da Comedia Eufrosina com tradução de Don Fernando de Ballesteros e Saabedra e prefácio de Francisco de Quevedo y Villegas ${ }^{27}$.

Natural de Villahermosa e regedor de Villanueva de los Infantes, local a que esteve vinculado toda a vida, o capitão Ballesteros (1576-1657), era «un verdadero ejemplar del hombre del Renacimiento en el Campo de Montiel» ${ }^{28}$. Ballesteros pertence ao círculo das figuras artísticas mais salientes da época, entre elas, o humanista Jiménez Patón que Ihe dedicou a sua Elocuencia española, e escritores como Cervantes, Quevedo ou Lope de Vega, que também Ihe não pouparam louvores.

A tradução é dedicada ao infante Don Carlos. José de Valdivielso (1560?-1638) amigo, entre outros, de Lope de Vega e de Cervantes, escreveu sobre a Comedia Eufrosina um parecer, lendo-se na sua Aprovación o seguinte:

La Fabula es sentenciosa, y exemplar, despierta avisos, y avisa escarmientos, devera al traductor Castilla, estos divertimientos, y Portugal estos honores. Este es mi parecer. Salvo, \&c. En Madrid, en veinte y nueve de Otubre de 1630. El Maestro loseph de Valdivieso ${ }^{29}$.

O célebre humanista Jiménez Patón (1569-1640) escreve em Villanueva de los Infantes o seu texto Aprovacion Del Maestro Bartolome Ximexez Paton para a edição da Comedia Eufrosina, chamando ao tradutor Ballesteros «segundo autor». Jiménez Patón foi também comediógrafo, condiscípulo e grande admirador da obra de Lope e, dada a proximidade do senhorio da Torre de Juan Abad com Villanueva de los Infantes, terá conhecido seguramente Francisco de Quevedo.

Para esta edição castelhana da Eufrosina, Francisco de Quevedo (1580-1645) escreveu também um texto de apresentação da comédia portuguesa intitulado $A$ los que leyeren esta comedia:

Esta Comedia Eufrosina, que escríta en Portugues se lee sin nombre de autor, es tan elegante, tan docta, tan exemplar, que haze lisonja la duda que la atribuye a qualquier de los mas doctos escritores de aquella nacion. Muestra igualmente el talento y la modestia del que la compuso; pues se calló tanta gloria que oy apenas la conjetura halla sujeto capaz a quien poder atribuirla ${ }^{30}$.

27. Em 1735, foi reeditada a tradução por D. Blas Nasare, pseudónimo de D. Domingo Terruño QuexiIloso, ambas de Madrid. Em 1910, Menéndez y Pelayo publica uma $3^{a}$ edição da comédia em Orígenes de la Novela. Entre outros, a edição castelhana encontra-se sem o Proemio, sem o Prologo e sem Carta da Índia que Zelótipo entrega e lê à prima Sílvia de Sousa, na cena $5^{a}$ do II acto. Presentemente, dois investigadores, Antonio Bernat Vistarini da Universidade das Ilhas Baleares e John T. Cull do College of the Holy Cross, Worcester, preparam uma nova edição castelhana.

28.Rodríguez Huéscar, 1982, p. 26.

29. Comedia de Eufrosina (1631).

30. Francisco de Quevedo, «A los que leyeren esta comedia», Comedia de Eufrosina (1631). 
Num estudo intitulado Ventos de Espanha - A Eufrosina de Jorge Ferreira de Vasconcelos - Uma tradução castelhana pouco conhecida, em 2008, falei desta tradução e do contexto cultural e político em que apareceu, chamando a atenção para o facto de o ano de 1631, em que sai a tradução da Eufrosina, ter sido um ano de intensa actividade editorial desenvolvida por Francisco de Quevedo, que edita fray Luis de León e dá ao prelo textos de Francisco de La Torre.

A versão castelhana da Eufrosina está no cerne deste intenso labor editorial, interligando escritores, editores, aprovadores, mecenato, que actuavam em um tempo e num lugar: Villanueva de los Infantes. Dito doutro modo, a tradução da Eufrosina de Fernando de Ballesteros, o prólogo de Quevedo, as diversas aprovações da comédia portuguesa, de José Valdivieso e de Jimenez Patón, que culminou com a edição castelhana de 1631, deu a Lope a oportunidade a voltar a publicar obras suas, num contexto editorial difícil, dada a proibição de imprimir comédias por essa altura em Espanha.

Jaime Moll, em Porque escribió Lope La Dorotea, aborda a situação editorial das primeiras décadas do século XVII, a suspensão da concessão de licenças para impressão de livros de comédias no período entre 1625 e 1634, notando quanto essas limitações administrativas haviam impedido Lope de Vega de publicar as suas comédias. Segundo o investigador, verificou-se à época uma supressão total de edições. A excepção foi a edição da Eufrosina que não se ajustava completamente à ideia de obra representável.

Ainda que de forma não habitual "Lope buscó una solución digna de Lope", ultrapassando a proibição, ao propor para publicação a Dorotea, apresentando-a como se sabe, não como novela ou comédia mas, como «dialogo en prosa" num primeiro momento -assim figura na licença-, para optar depois pela denominação de «accion en prosa». Diz-nos Jaime Moll:

Lope, en este «dialogo en prosa», adopta la forma de la Comedia de Eufrosina. Ya se han referido a las posibles influencias de esta obra varios críticos literarios. Aqui nos interesa sólo destacar el hecho de que Lope adoptara la forma externa de la Comedia de Eufrosina, la unica comedia - repetimos-cuya publicación fue autorizada por el Consejo de Castilla en estos años ${ }^{31}$.

Lope aproveitou, pois, a edição da Eufrosina, uma fenda na vida editorial ao tempo, para romper a proibição e dar a conhecer a sua Dorotea. Adoptou o modelo formal da comédia portuguesa de Jorge Ferreira Vasconcelos, recorrendo à prosa e a cinco actos com múltiplas cenas e, tal como este o havia feito, dando também o nome da protagonista à obra.

Assim, Lope oferece aos seus leitores uma obra original, precedida do elogio feito por Quevedo à comédia de Vasconcelos em particular e, em geral, às comédias do próprio Lope, um texto que figurava no prólogo da La Eufrosina em 1631. 
Em fins de 1634 é levantada a proibição mas, entretanto, Lope já havia publicado a Dorotea em 1632, um ano depois da saída da Eufrosina em castelhano.

\section{LA DOROTEA DE LOPE DE $1632^{32}$}

No notável prólogo que nos deixou Eugenio Asensio na edição da Comedia Eufrosina, a princeps de 1555, o erudito lusitanista diz-nos que um dos seus propósitos foi pôr a claro os íntimos laços da obra de Jorge Ferreira de Vasconcelos com a literatura espanhola do tempo e com o humanismo europeu. Para E. Asensio, a Dorotea tem muitas afinidades com a Eufrosina ${ }^{33}$.

José Manuel Blecua, na sua edição da Dorotea, ao procurar os pontos de contacto entre esta obra e a de Rojas, diz-nos que Lope conserva da Celestina a estrutura formal e a acção em prosa dialogada, mas que as personagens têm naturezas e desenvolvimentos bem diferentes. Segundo ele, na Dorotea, Lope combina poesia e realidade, sendo uma espécie de relato autobiográfico cuja estrutura segue a da Celestina e a da Eufrosina.

Veja-se que no paratexto Al Teatro que, segundo J. M. Blecua, todos os críticos concordam ser da pena do próprio Lope, este fala sobre as comédias da Grécia e de Roma acrescentando que

y entre las nuestras, más cerca de nuestros tiempos, La Celestina castellana e La Eufrosina portuguesa. Demás que en La Dorotea no se ven las personas vestidas, sino las acciones imitadas ${ }^{34}$.

As afinidades entre a Dorotea de Lope e a Eufrosina de Vasconcelos são a vários níveis: no temas do amor e do carácter amoroso dos portugueses, da língua, da inconstância da fortuna e da fugacidade da vida; na extensão do texto e na erudição; no tipo de enunciação usada pelas personagens, que dá mostras da força e da agilidade e do estilo destes dois grandes expoentes da literatura ibérica.

\subsection{O amor e o carácter amoroso dos portugueses}

António José Saraiva dizia que: «É [...] através da poesia que o Português manifesta o seu ponto de vista filosófico, quer dizer, a sua maneira de estar no mundo» ${ }^{35}$. Para este crítico, a poesia portuguesa fala muito do amor, a começar «pelas cantigas de amigo, que têm o amor como tema principal» continuando depois no

32. La Dorotea é escrita em 1631, ano da tradução castelhana de Ballesteros, e publicada em 1632, por um Lope septuagenário, rememorando os seus amores adolescentes com Elena Osório, casada com um cómico, nas Índias. Embora o autor diga que «Escribí La Dorotea en mis primeros años, y habiendo trocado los estudios por las armas», sabe-se pelo próprio Lope que o assunto é história ficcionada (Blecua, 1996, p. 89).

33. Asensio, 1951, p. LXXXVIII.

34. Blecua, 1996, p. 93.

35. Saraiva, 1993, p. 71 
século XVI com Bernardim Ribeiro e Camões. Saraiva lembra um epigrama de Lope de Vega sobre o sentimento amoroso à portuguesa, que muito impressionava os nossos vizinhos castelhanos:

A un portugués que llorava/ Preguntaran la ocasión Respondió que el corazón/ y que enamorado estava. Por minorar su dolor/ le perguntaran «de quién?» respondió: «Pues de ninguén/lloro de puro amor» ${ }^{36}$.

Ora, o amor é central na Comedia Eufrosina. Veja-se a ideia do amor português, do «amor puro» em Ferreira de Vasconcelos, na $5^{\mathrm{a}}$ cena do IV acto no discurso eloquentemente servidor da personagem Zelótipo, o mancebo apaixonado pela donzela Eufrosina:

E não me negareis ser a principal incrinação Portuguesa, [...] estimarem as moIheres sobre todos. Porque o engenhoso Italiano dessimula o amor [...]. O alegre Francês trabalha contentala per serviços, cantigas e festas [...]. O frio Alemão ama brandamente [...] Só o Português, amego e timbre dos espanhois, e grimpa de todas as nações, como atilado, gentil, galante e nobre esposo, compadece todos os efeitos do amor puro, não consinte mal em sua dama, não sofre verse ausente dela, busca de noite e de dia onde e como a veja, queria sempre estar com ela, emagrece com cuydados e maa vida [...] queymasse per dentro em pensamentos, que humilde representa com lagrimas e sospiros, sinais de verdadeyra dor: [...] constante na sua fé, chama sempre por ela em suas afrontas, como a alcança nunca a leixa té morte e assi a faz senhora de si mesmo [...]. Determinado em viver e morrer com ela se desespera, matase, ou faz estremos mortais, tudo isto e muyto mais se acha no bom Português, qual foy el rey Dom Pedro ${ }^{37}$.

Nesta comédia portuguesa, todas as personagens vivem para o Amor, excepto Filtra, a alcoviteira, que vive dele. Vénus é a figura tutelar desta obra quer se afirme como amor casto, quer se inflame como amor sensual. Aliás, enquanto tema do amor omnipotente, vai permitir a Vasconcelos dissertar sobre algumas ideias controversas na época e que dão que pensar. Por exemplo, quando Zelótipo remata a sua apologia ao amor dizendo a Cariófilo que «homem muyto namorado nunca fez muytas baixezas», Cariófilo contrapõe, advertindo que:

E querereis sostentar que sem amor tudo he nada, ora tomais hũa ennovada e graciosa seyta, pouco differe essa da commua que se levantou em Olanda, não ha quem não seja enganado com a sua openião ${ }^{38}$.

Esta «religião do amor em Portugal» casa sobremaneira com a sensibilidade de Dorotea para quem «Amor no es margarita para bestias» ${ }^{39}$. Na Dorotea, na cena passada no Prado, o «caballero» Dom Fernando conta a Felipa a sua desdita amo-

36. Saraiva, 1985, p. 89 .

37. Vasconcelos, Eufrosina, pp. 312-314. Seguimos neste estudo a edição da Comedia Eufrosina de Eugenio Asensio, de 1951.

38. Vasconcelos, Eufrosina, p. 314

39. Lope de Vega, Dorotea, p. 171. 
rosa com Marfisa e como ambos com o desgosto romperam a chorar atrás da porta, misturando-se «as palavras com as lágrimas». Felipa não resiste a comentar:

Gran llorador debéis de ser.

A que Dom Fernando responde:

Tengo los ojos niños y portuguesa el alma... ${ }^{40}$

A dama Dorotea é leitora dos grandes poetas portugueses comprazendo-se nos versos que estes dedicam às suas damas e que assim as eternizam, como seja: a Diana de Montemayor; a Violante de Camões; a Silvia de Bernardes; a Leonor de Corte Real, mas sobretudo cita na poesia Camões ${ }^{41}$.

\subsection{A língua portuguesa}

Outro tópico reclamadíssimo nas obras de Ferreira de Vasconcelos é o da língua portuguesa por contraposição ao latim. No prólogo diz-nos João D'Espera Deos:

e a portuguesa [...] e tam rica que lhe achareis alfayas próprias de que as outras carecem: [...] porque os homens fazem a lingoagem. [...] E se os Portugueses se prezassem dela como das armas, leyxariam escrituras de mores façanhas que os Hebreos de incredulidades, os Gregos de fabulas, e os Latinos de deoses ${ }^{42}$.

Ou na $2^{\text {a }}$ Cena do III Acto:

CARIOPHILO:- Nenhũa cousa podemos dizer que já não fosse dita, mas o amigo [...] tem por tanto convertelo em Portugues, como se fosse Homero ${ }^{43}$.

Lê-se na Dorotea, na $4^{\text {a }}$ Cena do III Acto:

LUDOVICO: porque el poeta, a mi juicio, ha de escribir en su lengua natural; que Homero no escribió en latín, ni Virgilio en griego, y cada uno está obligado a honrar su lengua, y así lo hicieron el Camoes en Portugal y en Italia el Tasso ${ }^{44}$.

Embora a língua seja um topos comum ao tempo, o que interessa aqui salientar é a sintonia que se encontra em Lope com o campo literário português, especificamente na prosa com as obras de Vasconcelos ainda que o nome do escritor

40. Lope de Vega, Dorotea, p. 321. Segundo Blecua: «Tener el alma portuguesa valía lo mismo que tener alma tierna, Ilorosa, enamoradiza». Abundan mucho los testimonios. Comp: «iQué lisonjero venía!/ -No es lisonja; que amor es. / -Debéis de ser portugués/pues tan presto os derretís» (Lope, Santo negro Rosambuco, p. 363b). Blecua, 1996, p. 321.

41. Lope de Vega, Dorotea, p. 171.

42. Vasconcelos, Eufrosina, p. 8.

43. Vasconcelos, Eufrosina, p. 191

44. Lope de Vega, Dorotea, p. 267.

HIPOGRIFO, 3.2, 2015 (pp. 179-201) 
português nunca seja mencionado, dado o anonimato da obra, e, na poesia, com Camões ${ }^{45}$.

\subsection{A fugacidade da vida}

Sobre o sentimento da fugacidade da vida, ouçamos Sílvia de Sousa amiga e confidente da donzela Eufrosina, na $7^{\text {a }}$ cena do IV acto:

Tudo hé vento, vem a velhice, seca aquela flôr: como rosa em que hum dia começa e acaba, assi passa nossa fermosura ${ }^{46}$.

E esse sentimento e consciência da vida como breve caminho para a morte na Dorotea na $10^{\mathrm{a}}$ cena do $\mathrm{V}$ acto:

DOROTEA: Toda la vida es un día: ayer fuiste moza, y hoy no te atreves a tomar el espejo [...] Todo llega, todo cansa, todo se acaba» ${ }^{47}$.

Como interpretar o tipo de enunciação de Sílvia de Sousa, a jovem donzela de companhia de Eufrosina, quando comparado com o da dama Dorotea? É a revisitação de um tópico? Uma apropriação? Uma adaptação? Uma reescrita?48

\subsection{As personagens femininas: damas, mães e alcoviteiras}

Algumas personagens da Dorotea trazem-nos à memória personagens de Vasconcelos. Por exemplo, Dorotea, dama casada, com o marido ausente nas Índias, ama desesperadamente Dom Fernando, que é sustentado por esta, e com quem mantém uma relação de cinco anos. Não se encontra este tipo de personagem na

45. Na $2^{\text {a }}$ cena do II Acto, Dorotea diz a propósito dos enganos do Amor:

DOROTEA: Verdad es que yo no tengo esperanza, porque solicité conmigo estes engaños, y podría decir lo que Luis de Camoes con tanta gracia, como otras muchas cosas, en su lengua portuguesa, quejándose de Amor: Que naon pode tirarme as esperanças

Que mal me tirará o que eu naon tenho

CELIA: Con qué gracia hablaste la lengua portuguesa! Para que no la tendrá tu donaire?

DOROTEA: Ella es dulcísima, y para los versos la más suave. Lope de Vega, Dorotea, p.168.

46. Vasconcelos, Eufrosina, p. 236.

47. Lope de Vega, Dorotea, p. 475

48. Outro tópico abordado por Lope na Dorotea é o da inconstância da vida e da fortuna. Camões (figura tão próxima de Lope em natureza e nalguns aspectos da vida; desterro, enganos, ciúmes, vinganças), é uma vez mais chamado, na $3^{\mathrm{a}}$ cena - $V$ acto, para justificar o esquecimento e ingratidão e o seu desejo de vingança da amante:

DON FERNANDO: Oh tiempo! Oh amor vengado! Oh mudanzas de fortuna! Oh condición humana! Donde viene tan bien lo que dijo en aquel soneto el ilustre portugués Luis de Camoes:

Mudanse os tempos, mudanse as vontades,

mudase o ser, mudase a confiança;

todo mundo he composto da mudança,

tomando sempre novas qualidades (Lope de Vega, Dorotea, p. 437). 
Eufrosina, mas podemos encontrar alguma proximidade entre a dama Dorotea e a jovem cortesã Florença da Comedia Ulysippo.

A dama portuguesa, sendo objecto de desejo de vários homens, é atormentada pelos ciúmes de Hipólito e perseguida pela ganância da mãe que, tratando-a como mercadoria, pretende fazer muitos genros de uma só filha. Florença tem duas armas poderosas: a beleza e a palavra. O seu discurso é enérgico e sentencioso. Luta contra Hipólito porque o ama e também sente ciúmes, luta contra si própria e luta por Hipólito contra a mãe, suplicando-Ihe que esta o deixe amá-lo, só a ele, pois tem a esperança de com ele casar. Na demanda desse amor que a nobilitará, é afirmativa, destemida, colérica, suplicadora, galante, mundana e tremendamente apaixonada.

Também a personagem Teodora, a mãe de Dorotea, nos faz pensar na figura de Macarena, mãe de Florença, «a bella», personagem atrás referida. Ambas, Teodora e Macarena, querem vender as filhas a um homem rico, exigindo que estas acabem a relação mantida a seu gosto, com os respectivos amantes. Ambas as mães, não mostram grandes escrúpulos em negociar as filhas, a troco de dinheiro. Ambas são mulheres sós e sem marido.

Por fim, a alcoviteira Gerarda da Dorotea parece aparentar-se mais com a alcoviteira Filtra da Eufrosina do que com a madre Celestina de Rojas. Se Gerarda é uma «buena nieta» da Celestina, segundo o parecer de Blecua ${ }^{49}$, é igualmente uma filha da alcoviteira portuguesa, na sua arte de adaptar a linguagem à situação, na destreza com que maneja e encadeia com «Uñas de gato y hábito de beato» os refrões no seu discurso ${ }^{50}$.

\subsection{Personagens masculinas: o cortesão pobre, poeta galante}

Embora por vezes a personagem Dom Fernando, poeta, culto e engenhoso, muito literato, lacrimoso e apaixonado até à medula dos ossos por Dorotea possa lembrar-nos a figura de Zelótipo, o amante zeloso da donzela Eufrosina, no entanto, no seu todo, adequa-se mais à personagem Cariófilo, figura imensamente sedutora e don juanesca, pícara e pouco escrupulosa. Damos aqui o exemplo tomado da $7^{\mathrm{a}}$ cena - II Acto:

CARIOPHILO: Finalmente fomos a monte, aventurey o resto, [...] e confessovos que fiquey sem fôlego. [...] toda a graça foy passadas as escaramuças, ouvir os seus queyxumes e maas venturas, o culparse e fazerse morta.

\section{ZELOTYPO: Vós que Ihe dizieis?}

CARIOPHILO: Eu riame, e lançava tudo aa zombaria, tomeya nos braços bebendolhe os rios de lagrimas, e pola consolar comecey fazerlhe mil juramentos que o coração desdezia ${ }^{51}$. 
Este cinismo patente em Cariófilo encontra-se em Dom Fernando, que de amante choroso passa a vingativo não esquecendo ofensas sofridas. Dom Fernando vive à conta de Dorotea como anteriormente já vivia às custas de Marfisa. É mantido pelas mulheres, não se inibindo de dizer que deixou Dorotea «casi desnuda» ${ }^{52}$.

Temos vindo a referir o modo como a Eufrosina serviu de modelo formal e inspirador para a Dorotea. Tal como Ferreira de Vasconcelos o havia feito nos textos das suas comédias, Lope insere romances e sonetos na sua Dorotea. Igualmente as suas personagens transpiram literatura e os refrões abundam e formam um encadeado no discurso das personagens.

Mas, se se verificam tantos pontos de contacto entre a Eufrosina e a Dorotea, há igualmente, e não com menor incidência, particularidades discrepantes entre os dois dramaturgos. O que em Vasconcelos é resguardo e segredo, em Lope é exposição e confronto de ideias. Vasconcelos parece esconder-se. Não só não assina nenhuma obra, como faz pouquíssimas menções a figuras do seu tempo, não dando quase nunca ao seu leitor informações sobre o seu mundo e sobre o seu círculo de relações.

Lope, ao invés de Vasconcelos, coloca-se dentro da própria obra quer como escritor, identificando a autoria da sua obra poética ${ }^{53}$, quer quando num registo claramente auto-biográfico e de auto-apresentação se afirma como autor ${ }^{54}$, fazendo alarde das suas convicções pessoais e comentando pessoas e situações, como é o caso quando se refere à proibição das comédias.

Também é frequente que Lope refira as suas fontes citando as obras e os seus autores. Mas, quando menciona a Eufrosina não menciona o dramaturgo, como acontece quando fala de Camões e da sua poesia, citando-o e nomeando-o. 0 facto de Ferreira de Vasconcelos nunca ter assinado a sua obra, como ainda esta ter entrado quase toda no Índex complicou a atribuição posterior. Veja-se que a edição seiscentista de Rodrigues Lobo continua a sair anónima, pelo que nem as edições da Ulysippo em 1618 e da Aulegrafia em 1619 que já vieram com atribuição não puderam inverter o estrago causado. A tradução castelhana de 1631 continua a sair anónima, sendo a autoria algumas vezes atribuída ao próprio tradutor. Só na edição castelhana de 1735 é que o nome do comediógrafo aparece como autor.

Por fim, um trabalho que tenha em conta as aproximações entre os textos das comédias Eufrosina, Ulysippo e Aulegrafia com a Dorotea, poderá dar conta das leituras e recepção de Lope de Vega quanto a obras de Jorge Ferreira de Vasconcelos. Vejamos agora uma outra obra de Vasconcelos, a Aulegrafia.

52. Lope de Vega, Dorotea, p.328. Também Hipólito, o amante da cortesã Florença da Comedia Ulysippo, tem este tipo de caracterização

53. Na $4^{a}$ cena- do I acto, diz Dom Fernando: Oye un romance de Lope. Lope de Vega, Dorotea, p. 121. 54. Veja-se na $2^{\mathrm{a}}$ cena do IV Acto o que diz César: ...y este Lope de Vega que comienza agora. Lope de Vega, Dorotea, p. 349 


\section{A AULEGRAFIA NA CASA DEL SOL - INVENTÁRIO DE 1623}

Preserva-se na Real Biblioteca em Madrid uma versão manuscrita da Comedia Aulegrafia, proveniente da Biblioteca do Conde de Gondomar. A convite desta Biblioteca escrevemos um estudo para a revista Avisos 63, a que intitulámos $A$ Aulegrafia de Jorge Ferreira de Vasconcelos na Casa del Sol, onde apresentámos um possível historial desse manuscrito, levantado algumas conjecturas quanto à sua transmissão.

A Comedia Aulegrafia foi publicada postumamente em 1619, por Dom António de Noronha, «o dos óculos», genro do dramaturgo, e «Dirigida ao Marquez de Alemquer, Duque de Francavilla, do Conselho do Estado de sua Magestade, Vice-rey, e Capitão General destes Reynos de Portugal», Dom Diego da Silva e Mendonça.

Era Dom Diego de Silva Mendoza, Conde de Salinas e Marquês de Alenquer (1564-1630), filho do famoso ministro de Filipe II, o português Rui Gomes da Silva e da belíssima Ana de Mendoza y la Cerda, príncipes de Éboli55.

O marquesado de Alenquer foi-Ihe concedido, por linha paterna, a 13 de Outubro de 1616. Foi vice rei de Portugal em 1615 e ainda de 1617 a 1621. Preparou as Cortes portuguesas de 1619 e representou Filipe IV em Lisboa em 1621. A par da sua actividade política, o Marquês de Alenquer e Conde de Salinas atingiu a glória na literatura espanhola, sendo considerado um eminente poeta, enaltecido pelos seus contemporâneos. Na Dorotea, Lope de Vega evoca a plêiade dos poetas do seu tempo. A um dado passo menciona «el Duque de Francavila» ${ }^{56}$.

Foi o Marquês de Alenquer e Conde de Salinas amigo do Conde de Gondomar, grande amante e colecionador de livros antigos, cuja biblioteca em Valladolid era frequentada, entre outros, por Francisco de Quevedo, ascendendo o número dos seus livros, segundo o inventário de 1623, a mais de 6500 volumes. Na sua vasta biblioteca encontra-se o referido manuscrito da Aulegrafia e um número impressionante de títulos portugueses bem escolhidos. Na rubrica «comedias» figuram: $A$ Comedia de Ulysippo, 8', Lisboa e a Comedia eufrosina de nuevo revista. $8^{\circ}$, Évora, 1566. Se juntarmos a este lote a cópia manuscrita da Comedia Aulegrafia, a trilogia conhecida fica completa.

Foi com base na dedicatória da edição da Comedia Aulegrafia dirigida a Dom Diego, Marquês de Alenquer e Conde de Salinas, e da amizade entre este e o Conde de Gondomar, que conjecturei a possibilidade de que a transmissão desse manuscrito tivesse passado, num primeiro momento, por uma oferta feita pelo próprio

55. Ruy Gómez de Silva foi valido do rei que Ihe ofereceu o título de Príncipe de Éboli, que lhe permitiu uma ascensão poderosa na corte, e um papel capital na política espanhola do século XVI, ao ponto de ser conhecido como «Rey Silva».

56. Lope de Vega, Dorotea, p. 347. Manuel Blecua assinala em nota de rodapé: «Exquisito poeta muy elogiado por sus contempóraneos. En Escorial, núm. 47, 1944, págs. 109-121, puede leerse una preciosa selección de sus poemas, escogida por L. Rosales (vid. Erasmo Buceta, «La obra poética del Conde de Salinas, en opinión de los grandes ingenios contemporáneos suyos», RFE, t. XII, 1925, págs. 16-29)», Blecua, 1996, pp. 347-348. 
genro e editor, Dom António de Noronha, ao Vice-rei de Portugal o Marquês de Alenquer, dado que lhe dedica a impressão seiscentista da comédia e, num segundo momento, o manuscrito ter sido presenteado por Alenquer/Salinas a Gondomar, já que este último gosta de livros e é amigo de Salinas ${ }^{57}$.

Assim sendo, e como tive oportunidade de assinalar no artigo da Avisos nº.63, de 2011, o manuscrito proporciona uma reflexão em várias frentes:

La coyuntura política y cultural específica de la época (monarquía dual) favorecía una circulación y recepción de obras en red, cuyo ejemplo podría ser consustanciado en el curioso triángulo Gondomar, Salinas y Noronha, en cuyo vértice se encontraría este códice de la Aulegrafía. En este sentido, es tentador lanzar la hipótesis de que la transmisión de este manuscrito estuviese ligada a un regalo de Salinas a Gondomar, el cual a su vez podría haber sido presentado por el propio yerno y futuro editor, don Antonio de Noronha, a Salinas, dado que le dedica la edición del año 1619 de la comedia ${ }^{58}$.

E se o manuscrito da Aulegrafia é, por enquanto, um puzzle incompleto na história da transmissão do livro antigo, não deixa por isso de constituir a ponta de um iceberg que ilumina as relações complexas de clientela política em tempo de Monarquia Dual, permitindo também, e o que é muito importante, verificar o tipo de expurgo realizado na edição de 1619. Este evidencia, no essencial, a tendência da censura já efectuada na Eufrosina, na edição de Lobo de 1616, mas com outras particularidades curiosas para o esclarecimento da actuação da censura em Portugal nesta época, e para a reflexão sobre a reescrita dos textos por mãos alheias. Para uma melhor compreensão do que poderá ter acontecido na circulação manuscrita dessa e doutras obras de Jorge Ferreira de Vasconcelos, atente-se no estudo de Fernando Bouza Álvarez sobre o sistema complexo por onde passava a posse, a oferta, a troca e o roubo dos manuscritos e também os usos e práticas da circulação manuscrita em Espanha e Portuga| ${ }^{59}$.

Por fim, e voltando a Lope e à sua recepção da obra de Vasconcelos, Eugenio Asensio, refere, no seu prólogo em 1951, que Lope se deixou levar pelo esplendor da Comedia Eufrosina, e que o tema da Dorotea segue de perto o tema da Aulegrafia, o amor que não resiste à passagem do tempo e ao desgaste dos ciúmes.

Lope de Vega al componer su obra maestra, se dejó llevar por los rumbos de la Eufrosina, combinando el canto llano de la pasión con el contrapunto de la literatura y el humorismo. No es una imitación, sino una superación. La distancia que va de la genialidad al ingenio se mide comparando La Dorotea con la Aulegrafia, cuyo asunto es muy parecido: la muerte de un amor a manos del tiempo y del agravio ${ }^{60}$.

57. O Conde de Gondomar é nomeado em 1596 corregedor de Toro e o conde de Salinas felicita-o por essa nomeação.

58. Pereira, Avisos, 63.

59. Bouza, 2002, pp. 27-75

60. Asensio, 1951, p. LXXXVIII.

HIPOGRIFO, 3.2, 2015 (pp. 179-201) 
Walter J. Schnerr, por sua vez, num artigo de 1971, intitulado «The "Theater" of Jorge Ferreira de Vasconcelos», retoma e segue a reflexão de E. Asensio dizendo que o tema da Aulegrafia antecipa o da Dorotea: «One theme anticipates the Dorotea, the theme of love that fails to withstand the test of time» ${ }^{61}$.

Mas há que lembrar que vingativas e brutais são algumas das cenas da Dorotea, tal como trágico é o desenlace final da obra, e que o mesmo não acontece nas obras de Vasconcelos. Até na mais sombria das suas comédias, como é o caso da Aulegrafia, Grasidel, o amante preterido pelos seus excessivos ciúmes, na última cena do $\vee$ Acto, aceitará resignado e não vingativo o casamento da sua amada com outro homem:

GRASIDEL: Por o que ja que vossa amiga a senhora Filomela, \& a sua donzela Dorothea estão contentes, \& satisfeitas do seu prospero acerto, não tenhamos pesar do seu prazer, nẽ magoa do seu gosto: que parece odio, ou inueja... ${ }^{62}$

O amor em Lope engendra ciúmes, inveja, vingança e morte. Em Vasconcelos e na sua Aulegrafia, prevalece a aceitação da escolha feita pelo outro, como uma espécie de castigo a que é sensato submeter-se. Diz o comediógrafo português «El-rei vai onde pode e não onde quer». E, embora Grasidel quisesse muito a Filomela, acabou por perdê-la, impotente, face à intriga imparável da dama palaciana Aulegrafia. Afinal, prevalece a ideia em Vasconcelos de que colhemos o que semeamos, e da consciência trágica da fragilidade dos sentimentos e do amor, já que «a condição, \& natureza do homem he querer, \& não querer». Nesse sentido, a conformação de Grasidel é, além de uma justificada e mitigada «pregação de paciente», um salutar exercício de superação e sobrevivência face aos reveses da fortuna e ao absurdo da existência humana.

\section{EPÍLOGO}

Muito mar de papel e tinta há entre Ferreira de Vasconcelos e Lope de Vega, até porque a recepção das obras de Vasconcelos por Lope não parece esgotar-se nos casos atrás referidos. Em 2009, deparámo-nos com uma informação a que antes não tínhamos dado atenção, constante no verbete de João Franco Barreto na sua Bibliotheca Luzitana, escrita por volta de 1670. A um dado momento é assinalada uma outra obra de Vasconcelos, lendo-se que:

O Livro de Sortes que foy de admiravel engenho, e delle Se ajudou Muito Lope da Veiga Em a sua Arcadia, tanto que pos Nela Os perceitos (sic) inteiros delles; e se prohibio pronto ${ }^{63}$

Efectivamente, é possível confirmar esta informação de João Franco Barreto, dado que a obra referida consta em diversos Índices Inquisitoriais portugueses: 0

61. Schnerr, 1971, p. 678

62. Vasconcelos, Aulegrafia, fol. 178

63. Barreto, Bibliotheca luzitana, fol. 674 
de 1564, 1581 e 1624. Igualmente se verifica a presença de matérias de astrologia judiciária em obras de Lope, quer na Arcadia ${ }^{64}$, quer na Dorotea ${ }^{65}$, pelo que a indicação é de grande valor e a ter muito em conta, ficando pendente a situação até que apareça um exemplar, intitulado Livro de Sortes, escrito em português, sem nome de autor. Trata-se pois de uma investigação em curso, que poderá trazer novas contribuições para o estudo comparatista entre a obra de Vasconcelos e a de Lope.

Para finalizar, foi de Espanha donde vieram alguns dos maiores admiradores da obra de Vasconcelos. Menéndez y Pelayo em 1910, em Orígines de la Novela, reedita a tradução de F. Ballesteros, dizendo-nos no seu estudo introdutório:

Mientras estas Celestinas se publicaban en Castilla, un ingenio portugués digno de mayor nombradía que la que logra en su patria y fuera de ella, componía tres largas comedias en su lengua nativa, tomando por modelo en todas ellas, y especialmente en la primera, el libro incomparable de Fernando de Rojas, pero sin calcarse tan servilmente como otros. Las comedias Euphrosina, Ulyssipo y Aulegraphia, de Jorge Ferreira de Vasconcelos, atestiguan, a la vez que el talento original de su autor, la influencia profunda que ejerció en Portugal la tragicomedia castellana desde el momento de su aparición. 66

Embora a apreciação de Menéndez y Pelayo o leve a colocar a questão sempre em função da obra de Fernando de Rojas, segundo Eugenio Asensio, as contas foram saldadas. Para o saudoso «pescador de pérolas» de obras portuguesas, Vasconcelos pagou às letras castelhanas o que delas recebeu ${ }^{67}$. Diz-nos Asensio, «de este modo se cerraba el círculo y Ferreira de Vasconcellos devolvía a las letras castellanas lo que de ellas había recibido» ${ }^{68}$.

\section{BIBLIOGRAFIA}

\section{Fontes manuscritas}

Lisboa - Biblioteca Nacional de Portugal

[Barreto, João Franco], Bibliotheca Luzitana. Autores Portuguezes - $1^{\text {a }}$. Parte Offerecida por, João Franco Barreto seu Autor natural da Cidade de LXa. Autor da Eneida Portugueza, 1670 (ca) fols. 673v, 674r e 674v. Fotocópia do texto manuscrito.

64. Veja-se a edição de Edwin S. Morby, ed. Castalia, a partir da p. 396.

65. Estas matérias aparecem nas cenas $3^{a}$ e $8^{a}$ do $V$ acto da Dorotea. Blecua assinala que para os conhecimentos astrológicos e astronómicos de Lope e da sua posição frente à ciência judiciária, é útil consultar o trabalho de Frank G. Halstead, 1939, pp. 205-219; Blecua, 1996, p. 440.

66. Menéndez y Pelayo, 1910, p. CCXXVIII.

67. Muito deve Portugal, os estudos literários e o teatro português, ao saudoso lusitanista, nascido em Murieta em 1902, que viveu grande parte da sua vida em Lisboa, vindo a falecer em Pamplona em 1996. 68. Asensio, 1951, p. 195, p. LXXXVIII. 
Madrid - Biblioteca Nacional de España

Índice y inventário de los libros que ay en la librería de Don Diego Sarmiento de Acuña, Conde de Gondomar, en su casa en Valladolid, hecho a último de Abril del año de 1623, Mss 13593-13594.

\section{Fontes impressas}

[Jorge Ferreira de Vasconcelos] - Comedia Eufrosina. Novamente impreffa \& emmendada por Francisco Roiz Lobo. Offrecida a Dom Gastão Coutinho. Em Lisboa, com Privilegio. Com todas as licenças e aprovações necessárias. Lisboa, por António Alvarez. Anno 1616, 4, 223 fols.

Comedia Ulysippo de Jorge Ferreira de Vasconcellos. Nesta segunda impressão apurada, \& correcta de algus erros da primeira. Com todas as licenças necessárias. Em Lisboa: Na officina de Pedro Craesbeeck. Anno M.DCXVIII, 278 fols.

Comedia Aulegrafia feita por Jorge Ferreira de Vasconcellos. Agora novamente impressa à custa de Dom Antonio de Noronha. Com todas as licenças necessarias. Em Lisboa. Por Pedro Craesbeeck. Anno 1619, 4, 186 fols.

[Jorge Ferreira de Vasconcelos] - Comedia Eufrosina traducida de lengua portuguesa en castellana por el Capitan Don Fernando de Ballesteros y Saabedra, «Introdução», de Don Francisco de Quevedo y Villegas. Madrid, en la Imprensa del Reino, Año de 1631. A costa de Domingo Gonçalez.

Vasconcellos, Jorge Ferreira de, Comédia Eufrosina, texto de la Edicion principe de 1555 con las variantes de 1561 y 1566, ed. Eugenio Asensio, Madrid, CSIC/ Instituto Miguel de Cervantes, 1951.

\section{Bibliografia passiva (sécs. XVI- XVIII)}

[Lopez de Úbeda, Francisco], Libro de Entretenimiento, de La Pícara Justina [...] de Francisco Lopez de Úbeda. Impresso en Medina del Campo, por Christoval Lasso Vaca. Año, M. DC. V.

[Lope de Vega] La Filomena, con otras diversas Rimas, Prosas, y Versos. De Lope de Vega Carpio. Año 1621. En Barcelona, Por Sebastian de Cornellas.

Index Librorum Prohibitorum, Editus auctoritate... D. Fernandi Mascaregnas... Ulyssip: ex officina Petri Craesbeck, 1624.

\section{Bibliografia geral}

Asensio, Eugenio (ed.), Comedia Eufrosina de Jorge Ferreira de Vasconcelos. Texto de la Edicion principe de 1555 con las variantes de 1561 y 1566, Madrid, CSIC/ Biblioteca Hispano-Lusitana, tomo I, 1951. 
Asensio, Eugenio, Alonso Núñez de Reinoso, «Gitano Peregrino» y su Égloga Baltea, Estudios Portugueses, Paris, F. C. Gulbenkian/Centro Cultural Português, 1974.

Bell, Aubrey F. G., (ed.), Comédia Eufrosina de Jorge Ferreira de Vasconcellos, conforme a impressão de 1561, publicada por ordem da Academia das Sciências de Lisboa, Lisboa, Imprensa Nacional de Lisboa, 1919.

Blecua, José Manuel (ed.), La Dorotea de Lope de Vega, Madrid, Cátedra, 1996.

Bouza, Fernando, Corre Manuscrito. Una Historia Cultural del Siglo de Oro, Madrid, Marcial Pons, 2002.

Lope de Vega, La Dorotea, ed. José Manuel Blecua, Madrid, Cátedra, 1996.

Lope de Vega, Arcadia, ed. Edwin S. Morby, Madrid, Castalia, 1975.

López de Úbeda, La Pícara Justina, Biblioteca de Autores Españoles, desde la formacion del linguage hasta nuestros dias, XXXIII, tomo II, cap. III, Madrid, Rivadeneyra, 1854.

Menéndez y Pelayo, Marcelino, $3^{a}$ edição castelhana com um estudo preliminar da «Comedia de Evfrosina, [Jorge Ferreira de Vasconcelos], Tradvcida de lengva portvguesa en castellana, por el capitan Don Fernando de Ballesteros y Saabedra, Al Sereníssimo Señor Infante Don Carlos, Con privilegio. En Madrid, en la Imprensa del Reino. Año de 1631. A costa de Domingo Gonçalez», Orígenes de la Novela, tomo III, Madrid, N.B.A.E., 1910.

Moll, Jaime, «Por qué escribió Lope La Dorotea», (Contribuición de la historia del libro a la historia literaria), 1616. Anuario de la Sociedad Española de Literatura General y Comparada, II, pp. 7-11, Madrid, Velograf, 1979.

Moreira de Sá, Artur, Índices dos Livros Proibidos em Portugal no Século XVI (Apresentação, estudo introdutório e reprodução fac-similada dos índices), Lisboa, Instituto Nacional de Investigação Científica, 1983.

Moura, Vasco Graça, Retratos de Camões, Lisboa, Guerra e Paz, 2014.

Pereira, Silvina, «Ventos de Espanha. La Eufrosina de Jorge Ferreira de Vasconcelos. Uma tradução espanhola pouco conhecida», in Act 15 - Teatro e tradução/palcos de encontro, Lisboa, Campo de Letras, 2008, pp. 369-393.

Pereira, Silvina, Tras a nevoa vem o sol - as comédias de Jorge Ferreira de Vasconcelos, Tese de doutoramento, Estudos Artísticos (Estudos de Teatro), Universidade de Lisboa, Faculdade de Letras, 2010, <http://hdl.handle. net/10451/6274> [28/05/2015].

Pereira, Silvina, «La Aulegrafia, de Jorge Ferreira de Vasconcelos en la casa del sol», em Avisos 63. Revista Digital da Real Biblioteca de Palacio, 2011, pp. 7-8.

Rose, Constance Hubbard, The Lament of Sixteenth-Century Exile, Rutheford New Jersey, Fairleigh Dickison University Press, 1971. 
Saraiva, António José, A Cultura em Portugal, Livro I, Lisboa, Bertrand Editora, 1985.

Saraiva, António José, Cultura, Lisboa, Difusão Cultural, 1993.

Schnerr, Walter J., «The "Theater" of Jorge Ferreira de Vasconcelos», in Homenaje a William L. Fichter: estudios sobre el teatro antiguo hispánico y otros ensayos, coord. David Kossoff y José Amor y Vásquez, Madrid, 1971, pp. 673-680.

Subirats, Jean, Jorge Ferreira de Vasconcelos - Visages de son oeuvre et de son temps, tomo I, Coimbra, Por Ordem da Universidade, 1982

Veiga, Tomé Pinheiro da, Fastigínia, ed. Ernesto Rodrigues, Lisboa, CLEPUL, 2011. 
